\title{
Analysing Changes in Discursive Constructions of Rural Areas* in the Context of Demographic Change. Towards Counterpoints in the Dominant Discourse on "Dying Villages"
}

\author{
Gabriela B. Christmann
}

\begin{abstract}
Empirically, this article is based on a research project on rural municipalities in structurally weak regions of Germany suffering from demographic change and attempting to find ways out of their crisis situation through novel approaches in community development. The example of the village of Treptitz in Saxony, which was investigated using an ethnographic discourse analysis, demonstrated that a small-scale discourse (of restricted spatial range) developed in the context of its innovative sewage works and biogas project. There, commonly shared knowledge could establish a context in which the village is considered an ingenious, socially intact, resolute and thus vibrant village; a village that actively pursues its prospects for the future. This small-scale discourse defies the wider demographic discourse, which, as the article shows, focuses primarily on "dying villages."

For the conceptualisation of the empirical observations, the article is based on the assumption that it is in communications and in public discourses - in particular specific recurrent contents on rural areas and demographic change - that specific knowledge elements and reality constructions of rural areas emerge and stabilise within society. This assumption includes the idea that when the content of public discourses on rural areas change, for example through small-scale discursive counterpoints, it is possible for new knowledge elements and new constructions of reality to develop. Against this background, the approach of a (new) discursive construction of spaces is selected as theoretical starting point for the analysis. By referring to the communicative-constructivism approach and by integrating the sociology of knowledge approach to discourse, it is perfectly suited for theoretically spelling out changing discursive constructions of rural areas in the context of demographic change.
\end{abstract}

Keywords: Demographic change $\cdot$ Structurally weak rural areas · Discourse Changing communicative constructions of spaces $\cdot$ Community development

\footnotetext{
Here, rural areas are to be understood as a category of space.
} 


\section{Introduction}

Given the perception that there is a lack of future prospects in rural areas in Europe, many people are confronted with the question of whether they should leave their native regions or stay. Indeed, migration from the country to the larger cities is nothing new; as always, cities with their variety of possibilities have been extremely attractive. However, what is happening these days in the context of emigration from - in particular peripheral - rural regions goes far beyond the historical phenomenon. Apart from the fact that the degree and rapidity of emigration has grown enormously, these emigration processes are embedded in radical demographic change, which, as is well known, is characterised by declining birth rates and the increasing ageing of society (cf. e.g. Birg 2003).

At the international level, much has been published on demographic change (cf. e.g. Bloom/Canning 2004; Andersen/Molander 2003; Hillebrand 2008; Williams et al. 2012; European Union 2011). One could say that an extensive international discourse is taking place on this topic, covering almost all spheres of life and making comprehensive future change a topic of discussion: the future economy, the labour market, the educational system, housing, different kinds of infrastructure, health care and nursing systems and not least old-age provision, to mention just the most important fields. Spatial aspects of demographic change are also a topic of debate, whereby shrinking processes and emigration from towns and municipalities in particular are discussed (cf. e.g. Müller/Meyer-Künzel 2007; Stryjakiewicz 2013). Structurally weak rural areas form a considerable part of this discourse (cf. e.g. Luck 2010; Bausch et al. 2014).

But what occurs if, at regular intervals, the sciences and the mass media communicate certain messages concerning demographic change (e.g. emigration)? This article is based on the assumption that it is in the context of communications and in particular of discourse that socially shared knowledge develops. In this case it is the knowledge of what structurally weak rural areas will look like in the future, given demographic change. This commonly shared knowledge in a society is not considered just a fantasy. It is powerful considering that realities are constructed in the course of the communicative and discursive establishment of shared knowledge (Berger/Luckmann 1987). In this context, the concept of reality means that commonly shared knowledge in a societal field becomes binding for everyday life in that field and that it finds expression in the actions of social actors.

However, constructions of realities are nothing static. Communications and discourses can change and with them new constructions of reality can occur. Geographically speaking, this means that existing constructions of rural areas being subject to demographic change may be newly constructed by way of discursive processes.

Indeed, there have been considerations about the relation between discourse and space for quite some time. The most prominent voices at the international level have been the Finnish human geographer Paasi (1989) and, in the field of new cultural geography in Germany, primarily Glasze and Mattissek (2009). However, it must be stated that in theoretical terms these concepts are not yet worked out 
in detail. Above all, they do not consider either the dynamic aspects or the role of social actors in geographical discourse. What thus remains unclear is, in particular, how change occurs in discourses.

This article aims to highlight the neglected aspects. Accordingly, the comprehensive research question is how social processes of changing discursive constructions of rural areas in times of demographic change can be understood in detail. This necessarily also includes questions of how these processes can be conceptualised theoretically and how they can be investigated methodologically.

In the following, I will report from an ongoing research project on innovative rural municipalities in Germany, which are insofar interesting as they are trying to re-create their rural spaces. The project "Innovations in Rural Municipalities. Conditions, Actors and Processes of Creative Community Development" (2015 to 2018) is funded and conducted by the Leibniz Institute for Research on Society and Space in Erkner (near Berlin), Germany. There, apart from the question of how innovation occurs in rural areas, the above research question of how processes of changing discursive constructions of spaces can be understood is part of the investigation. The focus of my presentation will be on one typical case (which is one of six cases in the project): the Saxon village of Treptitz. The presentation will be divided into three steps. In the first step (Section 2), I introduce the recently developed theoretical concept on changing communicative constructions of spaces (Christmann 2016) which is currently the most appropriate approach for understanding dynamic discursive constructions. The second step (Section 3) outlines the research design of the empirical project. There, an ethnographic discourse analysis is applied that has the capacity to investigate discursive processes and changing space-related constructions. In the third step (Section 4), I present empirical results from the research project. On the one hand I show that in the broader discourse on demographic change - both in social science based publications and in newspapers - structurally weak rural areas are dominantly constructed as areas of "dying villages" (Section 4.1). On the other hand, using the example of the Saxon village of Treptitz (Section 4.2) I work out in how far, within the small public of a local discourse, new constructions of rural spaces in terms of dynamic villages can nevertheless be observed. This is due to local actors creating novel approaches to community development while at the same time initiating an alternative discourse (Section 4.3). The main results will be summarised and reflected in Section 5.

\section{The theoretical approach of changing communicative constructions of spaces}

In social science-based spatial research, the theoretical premise of the social construction of space is widely recognised. In attempts to theoretically work out this premise, concepts have been developed to explain the existence of spaces as a result of the attribution of meanings, manifesting themselves in the form of geographical knowledge (for example in the form of a regional image) and/or as a result of human actions shaping spaces (cf. e.g. Lefebvre 1991). Only gradually, aware- 
ness developed of the fact that communication may also play a role in the social construction of spaces (cf. e.g. Paasi 1989; Schlottmann 2005; Pott 2007). However, until today this evidence is only weakly conceptualised. There are only a few theoretical approaches dealing with communications as a factor for the social construction of spaces. The few existing ones are inspired either by Luhmann's (1984) theory of autopoietic systems, such as Pott's (2007) system-theoretical approach on space and communication, or by Foucault's $(1974,1981)$ post-structural discourse analysis, which became central for Glasze's and Mattissek's approach on discourse and space (2009). However, in these approaches, communications are only considered in a highly abstract manner as processes within systems or structures that create knowledge. As we know, the approaches do not pay attention to the significance of social actors and communicative action in processes of knowledge production.

This is why this article is based on the theoretical approach of changing communicative constructions of spaces (cf. Christmann 2016), which emphasises that it is only through communications, for example among local actors, that mutually shared meanings can be produced and established and that it is only through communications that these meanings can be changed. Furthermore, spaces are seen as dynamic constructs being constantly newly constructed even if some spatial constructions appear to be highly institutionalised or physically fixed.

Communicative constructivism (initiated by Knoblauch) and the sociology of knowledge approach to discourse (developed by Keller) were referred to in order to be able to conceptually develop the idea of changing communicative constructions of spaces. Communicative constructivism (Knoblauch 2013, 2016, 2017) makes "communicative action" the focus of attention, whereby the term does not follow Jürgen Habermas's "Theory of Communicative Action," but is in line with Alfred Schütz's socio-phenomenological approach. This concept allows for grasping action dynamics, restructurings or negotiations of reality constructions and is based on the assumption that it is in the context of communicative action that (new) knowledge is produced and communicated. Keller's (2013, 2016; Keller et al. 2013) sociology of knowledge approach to discourse is inspired by Foucault $(1974,1981)$ when it analyses how knowledge develops in the context of discourse. But whereas in Foucault's approach - as mentioned above - acting subjects are only of minor significance, Keller's concept is based on an action-theoretical point of view, which makes it compatible with communicative constructivism. Accordingly, discourse is conceptualised as an ensemble of topically related communicative actions of a multitude of different (collective) actors communicatively negotiating key contents of the discourse.

Against the background of these theoretical cornerstones, Christmann (2016) suggested the approach of changing communicative constructions of spaces, which was developed based on two theoretical elements. The first element (cf. Christmann 2016: 96-101), which will only be mentioned briefly here as it is conceptually not of utmost importance for my article, describes the communicative and discursive processes by which members of a society commonly produce "first-time construction" of a specific - fictitious - spatial entity. The second part of the approach (Christmann 2016: 101-112) is crucial for my reflections, however. There, the chang- 
ing discursive construction of an already established space-related construction is conceptually developed step-by-step in a very detailed manner. That is, it develops how the new construction occurs through communicative action of (i) individual actors, (ii) groups of actors, and (iii) networks. Furthermore, it conceptualises how this occurs within smaller and larger discursive groups, and in particular in the context of (iv) mass-media discourses. Here it is essential - as indicated above - that the process is initiated by social actors and their ultimate actions. Individuals, groups of actors, networks or organisations are considered (collective) actors making more or less strategic attempts to topically influence the space-related discourse (according to their specific ideas) and to establish specific knowledge of the respective spatial entity. According to Christmann (2016: 111), the mass media also play a role within this process. They do not simply function as discourse arenas or news communicating agencies. Rather, due to journalistic action such as selecting and staging news, they appear as specific - powerful - actors. They are able to considerably influence the further public negotiation of specific discourse topics.

\section{Methodology: the ethnographic discourse analysis}

As pointed out in the previous section, changing discursive constructions of spaces should be seen as complex processes consisting of both communicative action by social actors and the dynamics of public media. This implies that the research design for the empirical investigation of such processes has to be complex as well. Accordingly, the research project on rural municipalities applied ethnographic discourse analysis (Christmann 2014) because it was particularly designed for analysing processes of social action as well as of discourses. As the term suggests, the ethnographic discourse analysis is a combination of two research fields: ethnography and discourse analysis. To be more precise, the approach of focused ethnography (Knoblauch 2005) has been crossed with the sociology of knowledge approach to discourse (Keller 2013). While focused ethnography can be used to analyse methods and contents of space-related (communicative) action by social actors within groups and networks, the sociology of knowledge approach to discourse allows investigation of space-related discourse topics and developing knowledge both in small and large groups. However, both approaches are typically regarded as research concepts that must not be confused with empirical research methods; this implies that specific methods of data collection and data analysis should be selected for the empirical research.

Against this background, the following methods were applied and data were collected:

(i) For the analysis of discourse topics (Keller 2013) related to demographic change and rural areas, 37 books (or individual book chapters) as well as 16 journal articles written by social scientists in Germany were collected for the period from 2000 to 2016; furthermore the data collection included 53 press articles accessible online by national, regional and local newspapers (searched for using keywords such as "rural regions", "villages", "demographic change" for the period 2000 to 2016) as well as websites, brochures 
and documents from innovative initiatives in the rural municipalities under investigation (for the period 2010 to 2016). These data were analysed using the coding procedures of the grounded-theory analysis (Strauss/Corbin 1990) in which recurring themes and typical semantics were identified. The method of grounded-theory analysis was also applied for all the other data collected within the research project (e.g. through interviews and participant observation).

(ii) For the analysis of the methods and contents of communicative action in local groups and networks in Treptitz, in the years of 2015 and 2016 participant observation (Madden 2010; Fetterman 2010) of seven local events as well as nine problem-centred interviews (Witze/ 1982, 2000; Hopf 2000) with local actors were conducted.

\section{$4 \quad$ Findings}

\section{1 "Dying villages" - towards the predominant discourse on demographic change in structurally weak rural areas}

Since the 1970s and increasingly the 2000s, there has been intensive, widespread social discourse on birth, death and emigration rates, which are carefully recorded in Western societies. At the same time, for slightly more than a decade in this discourse the consequences that demographic change is expected to have for society have been discussed. Predictions are made for this purpose and the consequences are usually considered negative. Typical examples are the debates on shrinking processes in cities and municipalities, dismantling requirements in the context of infrastructure or pension schemes problems in the context of the statutory pension insurance (Enquête-Kommission Demographischer Wande/ 2002; Berlin-Institut für Bevölkerung und Entwicklung 2009; Stula/Linz 2010). In Germany, since the 2010s there has even been talk of a demographic "crisis" (cf. e-politik 2010), which indicates a very high awareness of the problem.

Right from the beginning, rural regions have also been a topic of the extended discourse on demographic change, in the context of which there has always been an awareness of the fact that, due to different geographic locations and context conditions, demographic change would not affect all rural regions to the same extent. In Germany, primarily the so-called new federal states with their structurally weak rural areas have come into the particular focus of the discourse; even more so as demographic change started there very early and has been particularly intensive.

Meanwhile there are many publications by social science based spatial research that must be understood as part of the scientific discourse on demographic change. Typically, they deal with the question of what problems have to be expected. Furthermore, they discuss when and how adjustments can be made (cf. e.g. BMVBS/ BBSR 2009; Rosenmeyer 2010; Östlund 2011; Wegner 2012).

At the same time, developments and consequences of demographic change are regularly discussed in the context of a public - national, regional and local-media discourse. In it, journalists refer to scientific studies and communicate their contents in detail. As our discourse analysis revealed, however, they present these scientific 
results within a framework of dramatising metaphors, which in most cases even appear in bold type in the headlines. They typically speak of a "bleeding to death" of rural peripheral regions (cf. e.g. Lausitzer Rundschau: 8 December 2008, Frankfurter Rundschau: 8 April 2015), of future "empty landscapes" and roving "wolf packs" (cf. e.g. Süddeutsche Zeitung: 4 October 2012) as well as of "dying villages" (cf. e.g. Die Welt: 28 November 2011).

In the context of these communicative processes and specific semantics in the discourse on demographic change, we argue that new constructions of space occur. The regions previously referred to as "structurally weak rural areas," now became regions of "dying villages," of "emptiness" and thus of irreversible depopulation and desolation. By way of discourse they thus are not only made spaces that are structurally weak and lacking infrastructures, moreover they are made spaces without any future prospects, spaces that are abandoned by society.

As initially mentioned (Section 1), discursively created knowledge may become very powerful and results in social consequences. We can assume that rural inhabitants, given the negative predictions presented by the mass media at regular intervals (from further declining population via lacking prospects for the future as far as to future desolation), might come to the conclusion that they ought to leave their regions if they do not want to be counted among the losers. In this way, depopulation trends may increase, specifically among younger people (on this see Putzing 2006: 73-83). At least in the social science based literature there is evidence that rural inhabitants are aware of negative media reports on their regions (cf. Putzing 2006; Tobiassen et al. 2012: 19). Obviously, the knowledge of unfavourable predictions for the future communicated by the media is congruent with direct experiences rural inhabitants already have when it comes to local structural deficits. These include experiences of below-average economic productivity, insufficient career prospects, insufficient technological, social and services infrastructures, but often also of a reduced social and community life in the respective regions, which also supports depopulation trends (Müller/Siedentop 2003; Manthorpe/Livsey 2009). Never-ending emigration of rural inhabitants, however, starts what Weber (2012: 75) calls a "downward spiral" insofar as the economic opportunities of a region deteriorate increasingly due to a potential lack of workforce. Also infrastructures - if existent at all - are reduced, thus affecting the quality of life. The situation rural actors are confronted with - given the intermeshing of depopulation, negative discourses and negative structural developments - is thus that of a crisis. However, as crises force actors to give up their routines, they may accelerate development processes and initiate innovations.

\subsection{Socially innovative rural municipalities and the case of Treptitz}

What actually can be observed is that at least some local actors in rural regions have started taking up innovative ideas, experimenting with new solutions and slowing down the "downward spiral." They break with their previous action strategies, rethink their municipality and develop new practices. In the research project, this type of action is conceived of as a social innovation in community development since 
neither technological nor economic innovations are at the fore, although in some cases these types of innovation can be closely interlinked (Zapf 1989; Howaldt) Schwarz 2010). Social innovations are understood as novel practices, as "novel ways of achieving goals, in particular novel ways of organisation, novel regulations" (Zapf 1989: 177; own translation). In most cases, however, the novelty is to be understood rather as a "relative" than a "complete" novelty (Gillwald 2000: 11). It is a novel way of combining elements that are already known. What is important, however, is that these socially innovative local actors also start to discuss their municipalities in new ways and thus change the local discourse on their places. What they are doing, in abstract terms, is discursively creating new constructions of space.

As indicated above, the research project on rural municipalities selected six cases. All six municipalities are characterised by a marked rural settlement structure and a population density of less than 150 inhabitants per $\mathrm{km}^{2}$ (BBSR 2010). Furthermore, they are located in structurally weak areas insofar as the number of regular employees in the region is below average both regarding the respective federal state as well as the Federal Republic of Germany as a whole. The gross domestic product (GDP) per capita of the rural population is also below average. The rural municipalities are located in regions characterised by demographic change and by negative predictions regarding their future demographic development. Not least, their location is peripheral or very peripheral.

This article exemplarily presents the case of Treptitz. Treptitz belongs to the district of Nordsachsen. It is located between Dresden, Leipzig and Torgau in the midst of a nature preserve (cf. Fig. 1). The village has 130 inhabitants and belongs to the municipality of Cavertitz.

Fig. 1: The location of Treptitz in Nordsachsen

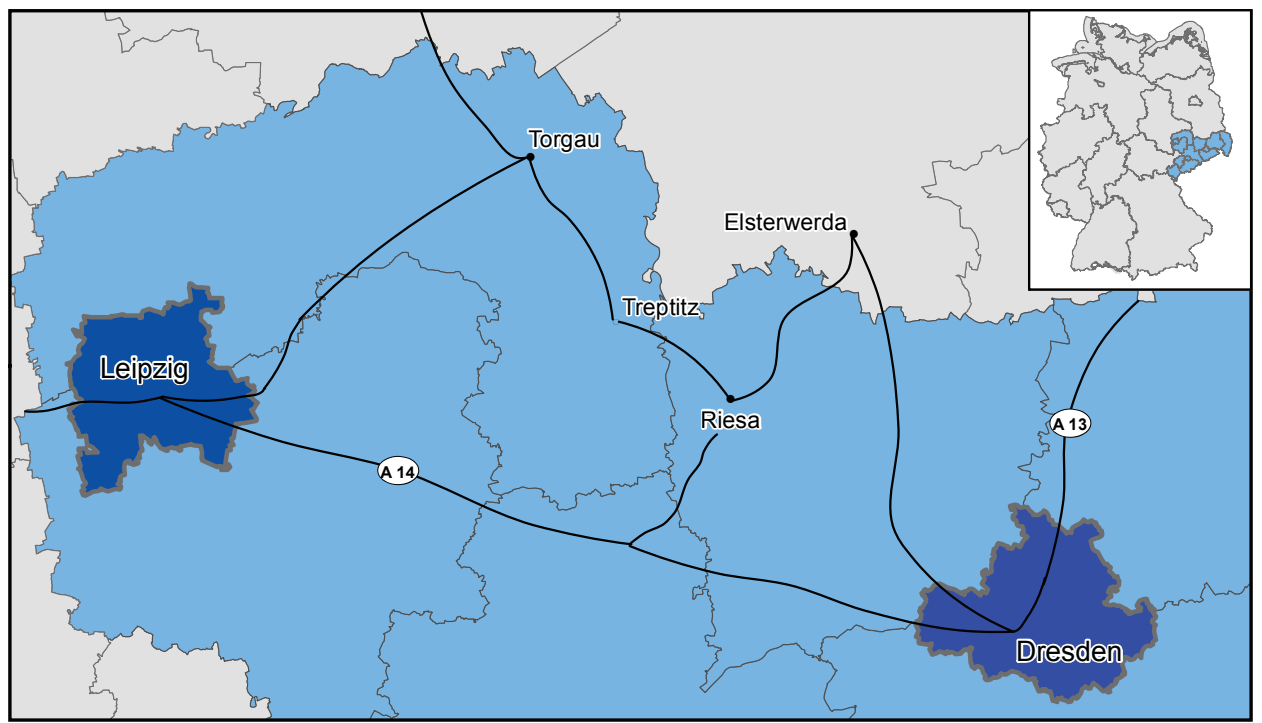

Source: Own design 
In recent decades, both the municipality of Cavertitz and the entire district of Nordsachsen have been much affected by demographic change. Within a period of slightly less than 15 years (between 2000 and 2014) Cavertitz lost about 18 percent of its population. In 2014, the population density was 32.6 inhabitants per $\mathrm{km}^{2}$ (cf. citypopulation.de 2014).

Tab. 1: Population trend in the municipality of Cavertitz (2000-2014)

\begin{tabular}{lccccccc}
\hline Year & $\begin{array}{c}\text { Population } \\
\text { trend }\end{array}$ & Year & $\begin{array}{c}\text { Population } \\
\text { trend }\end{array}$ & Year & $\begin{array}{c}\text { Population } \\
\text { trend }\end{array}$ & $\begin{array}{c}\text { Year } \\
\text { Population } \\
\text { trend }\end{array}$ \\
\hline 2000 & 2,721 & 2004 & 2,620 & 2008 & 2,444 & 2012 & 2,299 \\
2001 & 2,669 & 2005 & 2,571 & 2009 & 2,401 & 2013 & 2,282 \\
2002 & 2,642 & 2006 & 2,549 & 2010 & 2,372 & 2014 & 2,243 \\
2003 & 2,613 & 2007 & 2,507 & 2011 & 2,342 & & \\
\hline
\end{tabular}

Source: Statistisches Landesamt des Freistaats Sachsen 2016: 6

Predictions until 2025 are also negative for the entire district of Nordsachsen. Future losses are calculated at more than 12 percent compared to the year 2009 (cf. Statistisches Landesamt des Freistaats Sachsen 2016: 2). Thus, if we believe the predominant discourse on demographic change in structurally weak rural areas, Treptitz is a "dying village." However, the inhabitants of Treptitz see things differently.

\subsection{Innovative action and a small-scale discourse on a "vibrant village" in the context of demographic change}

\subsubsection{Innovative action: DIY construction of a sewage works and bioenergy supply}

The village of Treptitz is a case where social and technological innovations are interlinked. The social actors in the village use technology for their innovative community development. The starting point for their initiative is a sewage works problem, which at first sight had nothing to do with demographic change. However, the inhabitants of the village developed an approach to a solution that was at the same time an answer to the demographic problem. The challenge was that due to the location of Cavertitz, the existing EU guidelines demanded that the community provide for fully biological sewage works and that the calculated costs of a central installation for the whole municipality would have been so high that the municipality would have run up high debts lasting several generations. Given such a situation, the municipal council of Cavertitz, which had been dealing with the problem since 2007, decided that the individual villages should proceed independently when it came to the sewage issue.

The innovative project of village development. In this situation, the inhabitants of Treptitz proved to be ingenious and open for experiments. What makes the project 
a novelty is the fact that literally, i.e. even in the physical-material sense, an entire village took matters into their own hands.

The innovative project. Part I: constructing a sewage works. Instead of building expensive individual sewage works for each house, the plan foresaw the building of two treatment works for the whole village, which was much cheaper. The project was based on much DIY work by the inhabitants when it came to the installation of sewer pipes and the construction works in general. A first meeting of the inhabitants was a complete success. In September 2010, the Verein zum ökologischen Gewässerschutz Treptitz e. V. (Treptitz Association for Ecologic Water Protection) was founded, which enabled the village to act as a collective. There were astonishingly few conflicts during implementation of the plans. Only the lower authorities were responsible for some obstructions, but they were overcome. Soon young and old were digging everywhere in the village; they stood in the ditches and installed pipes.

The innovative project. Part II: supplying bioenergy. Inspired by innovative model projects from bioenergy villages, a second project was integrated into the running sewage works project that was supposed to be connected with the latter. To make the energy supply for the village much cheaper, in the course of construction works not only sewage pipes but also district heating pipes from the biogas plant of a nearby farm were installed for each household. In this way, they aimed to meet ecological criteria, make energy much cheaper for the inhabitants and, not least, increase the quality of life and attractiveness of the place. Right from the beginning, the latter goal in particular was of great significance for the actors.

One key individual and the villagers pulling together. One inhabitant who was a Treptitz native but had not always occupied a key position within the village community became a key individual in the process. Being a young graduate engineer and scientist at a university in Saxony, he was not considered a typical village dweller in this agricultural place. The fact that this actor's special field was hydraulic engineering and human settlement management and that he was thus capable of contributing extensive technological expertise as well as a network of other experts was crucial for the course of the project. Another decisive factor for the success of the project was that the local network as such consisted of the entire village community. The villagers supported the project right from the beginning with very few conflicts. The reason for this is the history of the village, which had experienced a similar, though smaller, community project during GDR times. At that time, the community installed cable and antenna technology for television in the village.

\subsubsection{A small-scale discourse on a "vibrant village" emerges and develops}

Soon the plans and activities of the crucial actors became the talk of the village. Within the small population of the village a discourse developed to which the inhabitants were very committed. The key individual was the starting point of the discourse since he introduced the novel solutions and promoted it in the whole village by talking with villagers individually, as we learned from conducting interviews with social actors of the village. Furthermore, village assemblies held in the fire brigade 
house at the beginning of the project were important events for the development of the small-scale (i.e. of the still very local) discourse, because the village community came together there and started to discuss the project and the future of the village. However, the founding of the association for ecologic water protection (Verein zum ökologischen Gewässerschutz Treptitz e. V.) in which most of the villagers became members was decisive for consolidating the discourse. By founding the association, the villagers created a network of collaborating inhabitants and of infrastructural measures that was needed to meet their visions. There, through association meetings the small-scale discourse was internally established and further developed. Through participant observations of some of these assemblies in 2015, we discovered how lively the meetings and discussions still are. By setting up a website, the association members laid the groundwork for external communication of their small local discourse.

Among other things, key messages were created for the website that at the same time confirmed the commitment of the village community. The following is a typical and essential statement:

"We are Treptitz, a village of 130 inhabitants at the fringes of Dahlemer Heide, and we are known for our community sticking together and being full of ideas." (http://treptitz.de/der-verein-2/; own translation).

In this way, the villagers of Treptitz show how they see themselves and their place. In terms of discourse analysis, a sort of knowledge order becomes obvious here in the context of which Treptitz is considered a village of ingenuity and solidarity. In this way, this rural place is socially constructed as a creative, vibrant space and not at all as a dying one.

Interview partners from Treptitz tell us that the inhabitants were so proud of what they achieved together that they told outsiders about their project at every opportunity. Even when on holiday they carried photos of the construction project with them to tell others about it. This indicates how the collective identity of the people of Treptitz was strengthened. Self-confidence was spreading as, after all, they experienced that people can take matters into their own hands and thus organise community development themselves.

In the context of the project and related discourse, the inhabitants' awareness increased that it is possible to find solutions for existing problems in rural areas provided there is sufficient "ingenuity" and vigour. The following statement by the Verein zum ökologischen Gewässerschutz Treptitz e. V. provides evidence of this:

"In contrast to the common demographic situation in Germany, Treptitz is a young place. Also, to keep our small village, which is in the middle of a rural area, attractive for young people in the long run we need an infrastructure that will be affordable for our children and is ecologically sustainable. Our goal is to make life in the country worth living and affordable, to prevent small places such as Treptitz from dying out." (http://treptitz.de/der-verein-2/; own translation).

The statement explicitly addresses the demographic situation that, at least as far as the issue of an ageing village community is concerned, is comparatively favour- 
able, as we are told, and should be preserved. The goal, it says, is to make sure that the village will be attractive and sustainable in the long run for young people in particular, and this goal is to be reached by means of a sustainable and affordable infrastructure. Interestingly, in this context the association refers to a crucial term from the predominant discourse on demographic change: that of "dying out." However, it is obvious that the association does not consider "dying out," as suggested by the discourse, to be the reality of the village. Rather, it works to prevent this suggested reality of dying out and to ensure that it will not happen in future. Treptitz presents itself as a village defying the process of dying out. By creating a new construction of place, a vision plays a role according to which the place is a good place to live, attractive and affordable. Thus, the village of Treptitz can be described as a village that, through its own small-scale discourse on demographic change, provides an alternative to the predominant negative discourse.

However, the discourse analytical investigations showed that between 2010 and 2014, the Treptitz approach to community development - with its marked discourse and remarkable local activities - found hardly any response in regional or national newspapers. Thus, there were hardly any reports on what was happening at Treptitz; at best the dates of events were announced. This makes a power structure obvious where the villagers with their small-scale discourse were sitting at the shorter end of the lever and the local and regional press continued to simply "overlook" the initiative. At best, there was one report that at Bockwitz, five kilometres away from Treptitz, negotiations were taking place about whether Treptitz might serve as a model for the problem of sewage works (cf. Torgauer Zeitung, 2 May 2014).

Thus, for a long time the discourse remained a small-scale one yet it had local effects since local knowledge grew in which the inhabitants began to consider their village a vibrant place with visions for the future. The new discursive reconstruction of space, which initially became manifest only by the villagers jointly inventing a positive future for their village, could even be implemented as a project in the context of the innovative approach.

\subsubsection{The small discourse grows into a large one-counterpoint in the dominant discourse on demographic change}

The media coverage changed in 2014 when the village and its association took part in the Innovationen querfeldein - Ländliche Räume neu gedacht (Innovations across Country - New Ideas of Rural Areas) competition held by Land der Ideen (Land of Ideas).

It is interesting how the people of Treptitz presented themselves in their application (excerpts from the application were published on the association website):

“We, as inhabitants of Treptitz, have together searched for and identified an inexpensive and environmentally friendly solution for our sewage disposal. Together with a local farmer we worked out and implemented a concept for our local heating in order to, in the long run and with a clear conscience, keep the rural area, particularly our own village, 
attractive and worth living in for our children in the future." (http://treptitz.de/land-der-ideen/; own translation).

Once again they emphasise that the project pursued the goal of making sure that the village will be attractive and worth living in future. Furthermore, the people of Treptitz explicitly call their project "innovative," probably in response to the concept of innovation demanded by the competition. After a detailed description of the technological aspects of the implemented project, the final, seventh point mentions the following social effects:

"7. Cohesion in the village has considerably strengthened; ' $I$ ' has changed to 'WE'. Our village is growing, in the meantime three young families have decided to move to Treptitz and build their homes here as a result of the favourable conditions provided by the village." (http:// treptitz.de/land-der-ideen/; own translation)

The beginning of the statement reflects the marked discourse at Treptitz on the social cohesion in the village, which - as stated above - was a crucial experience in the context of the project from the actors' point of view. It is remarkable that they also mention the fact that people moved to the village. The actors state that young families moved to Treptitz, thus demonstrating that their actions against "dying out" indeed achieved the intended result. The actual creation of a construction of space as a result of these actions is that of an ingenious, resolute and socially intact village with a high quality of life and a high degree of attractiveness, which - as a result of their innovative and sustainable solution for an infrastructural problem - may attract more young families to the village in the context of demographic change.

When, in autumn 2014, the jury of Land der Ideen announced Treptitz was the national award winner of the "environment" category and thus socially recognised the reality construction of the village, it became the topic of wider mass media discourse (cf. e.g. Eco-world, 9 September 2014; Leipziger Volkszeitung, 13 November 2014; Die Welt, 16 November 2014; Freie Presse, 23 November 2014). Both in regional and national newspaper articles as well as on important online forums, the headlines revealed the crucial message:

"Innovations Across Country: Everything Is All Right Thanks to Innovation at Treptitz" (Eco-World, 9 September 2014; own translation)

“These Ideas Will Save Our Villages from Dying Out" (Die Welt, 16 November 2014; own translation)

The messages communicated by the media emphasised most of all that rural innovations are possible and that in the context of demographic change they may save villages from dying out. New tones could be heard in the predominant discourse on demographic change, which up to then had been dominated by "dying villages." Other typical topics of the discourse in the context of the innovation at Treptitz were connected to the project being a model for others, to the success factors of the project and to the question of whether it could be transferred to other 
villages or municipalities (cf. e.g. Leipziger Volkszeitung, 8 September 2015; Freie Presse, 23 November 2014). However, Treptitz was only temporarily in the focus of media attention.

Indeed, the Treptitz project may be representative of countless other projects and small-scale discourses in rural regions where rural inhabitants have proven their ingenuity, originality and resolute cooperation - independently of competitions. However, they only rarely came into the focus of a wider mass media discourse and definitely not in the context of demographic issues. However, innovation semantics and competitions seem to be factors that attract extended media attention and thus also the attention of society. In this way, the predominantly negative discourse on rural areas in the context of demographic change is put into question.

Interestingly, for quite some time such small "bottom up" discourses have been supported by political "top down" activities. For example, based on a decision by the Federal Ministry of Education and Research, the Demographic Opportunity Year of Science was announced in 2013 to purposefully negotiate positive aspects of change in the public and to raise awareness of this trend - also when it comes to rural areas. In the following year the Deutschland - Land der Ideen initiative mentioned above started the Innovationen querfeldein competition (2014), which also aimed at emphasising innovative ideas particularly in rural areas and at making them publicly known.

If we try to express this phenomenon in terms of discourse analysis, it is, in a way, strategies by political actors through which new - socially shared - knowledge concerning rural areas in the context of demographic change can be established, thus allowing for the creation of broader new communicative constructs about rural spaces. In this context, these rural regions may also be seen as "vibrant" and "attractive" places.

\section{$5 \quad$ Summary and Conclusions}

The empirical analyses revealed that rural areas that initially were simply constructed as structurally weak, lacking in infrastructures and with low economic productivity within the discourse on demographic change in rural regions were given new constructs as they were presented as areas "bleeding to death." In particular in the public media discourse, it regularly became a topic of discussion whether these rural areas will be characterised by "dying villages," "empty landscapes," and "roving wolf packs in future." In this way, a space-related discourse was established in which perceptions of irreversible depopulation, emptiness and desolation became dominant with regard to rural regions (Section 4.1).

At the same time, however, further new constructions of rural areas were observed in the empirical data that contradict the predominant discourse on demographic change, as the case of Treptitz illustrates (Section 4.2).

What we could see was the following (Section 4.3) - and here, the approach of new communicative constructions of spaces (Section 2) was helpful in structuring 
and conceptualising the emergence of counterpoints in the dominant discourse on "dying villages":

- Actually, it is due to the local actors' innovative action and socially innovative initiatives in community development that new facets of the discourse have emerged, even though at first these facets were still restricted to a small-scale discourse.

- It is also due to the manifold communications on the future of the village that were very often organised by the key individuals of the initiatives. These communications happened in bilateral encounters as well as group discussions both in village assemblies and meetings of the newly founded local association.

There, from bottom-up so to speak, the villagers started a small-scale, local discourse in which the village was discussed in terms of creative potentials and innovative approaches. The actors began to rethink their rural space and to develop new knowledge. Thus, through communicative actions by key local players and finally by the entire village community, a small but effective discourse unfolded in which the construct of the village became that of an ingenious, socially intact, resolute and vibrant village. Moreover,

- this discourse even found its way into the wider media discourse on demographic change, which is due to the fact that the village took part in the Land der Ideen (Land of Ideas) competition and was announced as the national award winner of the "environment" category in 2014.

However, it also became obvious that it is difficult for actors in structurally weak rural regions to constantly make the creativity and the potentials of their regions a topic of discussion in the public media. By neglecting these potentials, the predominant newspaper discourse on demographic change still seems very powerful.

In summary, the approach of the communicative (new) construction of spaces (Section 2) proved helpful, because it allows us to conceptualise micro-processes of new discursive constructions of spaces in detail. For the empirical investigation, by the way, the ethnographic discourse analysis (Section 3) also proved an adequate approach for analysing social micro-processes in changing discourses.

\section{References}

Andersen, Torben M.; Molander, Per 2003: Alternatives for welfare policy: coping with internationalism and demographic change. Cambridge: Cambridge University Press.

Baur, Nina et al. (Eds.) 2008: Handbuch Soziologie. Wiesbaden: VS Verlag.

Bausch, Thomas; Koch, Madeleine; Veser, Alexander 2014: Coping with demographic change in the alpine regions. Actions and strategies for spatial and regional development. Heidelberg: Springer [doi: 10.1007/978-3-642-54681-5].

Beck, Ulrich 1994: Riskante Freiheiten. Individualisierung in modernen Gesellschaften. Frankfurt am Main: Suhrkamp.

Berger, Peter L.; Luckmann, Thomas 1987: Die gesellschaftliche Konstruktion der Wirklichkeit. Eine Theorie der Wissenssoziologie. Frankfurt a.M.: Fischer. 
Berlin-Institut für Bevölkerung und Entwicklung 2009: Demografischer Wandel. Ein Politikvorschlag unter besonderer Berücksichtigung der Neuen Länder. Berlin: Berlin-Institut [http://www.berlin-institut.org/publikationen/gutachten/demografischer-wandel. html, 05.01.2015].

Birg, Herwig 2003: Die demographische Zeitenwende: Der Bevölkerungsrückgang in Deutschland und Europa. München: C. H. Beck.

Bloom, David E.; Canning, David 2004: Global demographic change dimensions and economic significance. Cambridge: Cambridge University Press.

BBSR (German Federal Institute for Research on Building, Urban Affairs and Spatial Development) 2010: Raumtypen 2010 [http://www.bbsr.bund.de/BBSR/DE/Raumbeobachtung/ Raumabgrenzungen/Raumtypen2010_vbg/Raumtypen2010_alt.html, 15.06.2015]

BMVBS (Federal Ministry of Transport, Building and Urban Development); BBSR (German Federal Institute for Research on Building, Urban Affairs and Spatial Development) (Eds.) 2009: Ländliche Räume im demografischen Wandel. BBSR-Online-Publikation 34/2009 [urn:nbn:de:0093-ON3409R142, 05.01.2016].

Böhle, Fritz; Weihrich, Margit (Eds.) 2009: Handeln unter Unsicherheit. Wiesbaden: VS Verlag.

Bührmann, Andrea D.; Schneider, Werner 2008: Vom Diskurs zum Dispositiv. Eine Einführung in die Dispositivanalyse. Bielefeld: transcript.

Christmann, Gabriela B. 2010: Kommunikative Raumkonstruktionen als (Proto-) Governance. In: Kilper, Heiderose (Ed.): Governance und Raum. Baden-Baden: Nomos: 27-48.

Christmann, Gabriela B. 2013: Raumpioniere in Stadtquartieren und die kommunikative (Re-) Konstruktion von Räumen. In: Keller, Reiner; Knoblauch, Hubert; Reichertz, Jo (Eds.): Kommunikativer Konstruktivismus. Theoretische und empirische Arbeiten zu einem neuen wissenssoziologischen Ansatz. Wiesbaden: Springer VS: 153-184.

Christmann, Gabriela B. 2014: Investigating Spatial Transformation Processes. An Ethnographic Discourse Analysis in Disadvantaged Neighbourhoods. In: Historical Social Research 39: 235-256 [doi: 10.12759/hsr.39.2014.2.235-256].

Christmann, Gabriela B. 2016: Das theoretische Konzept der kommunikativen Raum(re) konstruktion. In: Christmann, Gabriela B. (Ed.): Zur kommunikativen Konstruktion von Räumen. Theoretische Konzepte und empirische Analysen. Wiesbaden: Springer VS: 89-117.

Di Luzio, Aldo; Günthner, Susanne; Orsetti, Franca (Eds.) 2001: Culture in Communication. Analyses of Intercultural Situations. Amsterdam/Philadelphia: Benjamins.

Dünne, Jörg; Günzel, Stephan 2006: Raumtheorie. Grundlagentexte aus Philosophie und Kulturwissenschaften. Frankfurt a.M.: Suhrkamp.

E-politik 2010: Deutschland in der Demographie-Krise [http://e-politik.de/artikel/ 2010/ deutschland-in-der-demographie-krise/, 15.06.2015].

Elias, Norbert 2004: Was ist Soziologie? Weinheim/München: Juventa.

Enquête-Kommission "Demographischer Wandel" 2002: Herausforderungen unserer älter werdenden Gesellschaft an den Einzelnen und die Politik". Schlussbericht. Drucksache 14/8800. Berlin [http://dipbt.bundestag.de/dip21/btd/14/088/1408800.pdf, 05.01.2016]

European Union 2011: Demography Report 2010. Older, more numerous and diverse Europeans. Luxembourg: Publications Office of the European Union.

Fetterman, David M. 2010: Ethnography. Step by Step. Newbury Park: Sage. 
Foucault, Miche/ 1974: Die Ordnung des Diskurses. München: Hanser.

Foucault, Michel 1981: Archäologie des Wissens. Frankfurt a.M.: Suhrkamp.

Gillwald, Katrin 2000: Konzepte sozialer Innovation. Paper der Querschnittsgruppe Arbeit und Ökologie P00-519. Berlin: Wissenschaftszentrum Berlin für Sozialforschung.

Glasze, Georg; Mattissek, Annika 2009: Diskursforschungen in der Humangeographie: Konzeptionelle Grundlagen und empirische Operationalisierungen. In: Glasze, Georg; Mattissek, Annika (Eds.): Handbuch Diskurs und Raum. Theorien und Methoden für die Humangeographie sowie die sozial- und kulturwissenschaftliche Raumforschung. Bielefeld: transcript: 11-59.

Häußermann, Hartmut et al. (Eds.) 1991: Stadt und Raum. Soziologische Analysen. Pfaffenweiler: Centaurus.

Hepp, Andreas 2013: Medienkultur. Die Kultur mediatisierter Welten. Wiesbaden: Springer VS.

Heuner, Ulf 2010: Klassische Texte zum Raum. Berlin: Parodos.

Hillebrand, Marten 2008: Pension systems, demographic change, and the stock market. Berlin: Springer.

Hoffmann, Carl A.; Kießling, Rolf (Eds.) 2001: Kommunikation und Raum. Konstanz: UVK.

Honegger, Claudia; Hradil, Stefan; Traxler, Franz (Eds.) 1999: Grenzenlose Gesellschaft? Verhandlungen des 29. Kongresses der Deutschen Gesellschaft für Soziologie, des 16. Kongresses der Österreichischen Gesellschaft für Soziologie, des 11. Kongresses der Schweizerischen Gesellschaft für Soziologie in Freiburg i. Br. 1998. Teil 1. Opladen: Leske + Budrich.

Hopf, Christel 2000: Qualitative Interviews - ein Überblick. In: Flick, Uwe; v. Kardorff, Ernst; Steinke, Ines (Eds.): Qualitative Forschung. Ein Handbuch. Reinbek bei Hamburg: Rowohlt: 349-360.

Howaldt, Jürgen; Schwarz, Michae/ 2010: Social Innovation. Concepts, Research Fields and International Trends [http://www.sfs-dortmund.de/odb/Repository/Publication/ Doc\% 5C1289\%5CIMO_Trendstudie_Howaldt_Schwarz_ englische_Version.pdf, 15.03.2015].

Keller, Reiner 2008: Wissenssoziologische Diskursanalyse. Grundlegung eines Forschungsprogramms. Wiesbaden: VS Verlag.

Keller, Reiner 2013: Doing Discourse Research. An Introduction for Social Scientists. London: Sage.

Keller, Reiner 2016: Die symbolische Konstruktion von Räumen. Sozialkonstruktivistisch-diskursanalytische Perspektiven. In: Christmann, Gabriela B. (Ed.): Zur kommunikativen Konstruktion von Räumen. Theoretische Konzepte und empirische Analysen. Wiesbaden: Springer VS: 55-78.

Keller, Reiner; Knoblauch, Hubert; Reichertz, Jo 2013: Der Kommunikative Konstruktivismus als Weiterführung des Sozialkonstruktivismus - eine Einführung in den Band. In: Keller, Reiner; Knoblauch, Hubert; Reichertz, Jo (Eds.): Kommunikativer Konstruktivismus. Theoretische und empirische Arbeiten zu einem neuen wissenssoziologischen Ansatz. Wiesbaden: Springer VS: 9-21.

Knoblauch, Hubert 2005: Focused Ethnography. In: Forum: Qualitative Social Research 6,3: Art. 44 [http://nbnresolving.de/urn:nbn:de:0114-fqs0503440, 10.05.2015].

Knoblauch, Hubert 2013: Communicative Constructivism and Mediatization. In: Communication Theory 23,3: 297-315 [doi: 10.1111/comt.12018]. 
Knoblauch, Hubert 2016: Über die kommunikative Konstruktion der Wirklichkeit. In: Christmann, Gabriela B. (Ed.): Zur kommunikativen Konstruktion von Räumen. Theoretische Konzepte und empirische Analysen. Wiesbaden: Springer VS: 29-53.

Knoblauch, Hubert 2017: Die kommunikative Konstruktion der Wirklichkeit. Wiesbaden: Springer VS.

Läpple, Dieter 1991: Essay über den Raum. Für ein gesellschaftswissenschaftliches Raumkonzept. In: Häußermann, Hartmut et al. (Eds.): Stadt und Raum. Soziologische Analysen. Pfaffenweiler: Centaurus: 157-207.

Lefèbvre, Henri 1991: The Production of Space. Cambridge: Blackwell.

Löw, Martina 2001: Raumsoziologie. Frankfurt a.M.: Suhrkamp.

Luck, Gary W. 2010: Demographic Change in Australia's Rural Landscapes. Heidelberg: Springer.

Luckmann, Thomas; Berger, Peter L. 1964: Social Mobility and Personal Identity. In: European Journal of Sociology 1: 331-344.

Luhmann, Niklas 1984: Soziale Systeme: Grundriß einer allgemeinen Theorie. Frankfurt: Suhrkamp.

Madden, Raymond 2010: Being Ethnographic. A Guide to the Theory and Practice of Ethnography. London: Sage.

Manthorpe, Jill; Livsey, Lynne 2009: European Challenges in Delivering Social Services in Rural Regions: A Scoping Review. In: European Journal of Social Work 12,1: 5-24 [doi: 10.1080/13691450802567440].

Miebach, Bernhard 2008: Prozess. In: Baur, Nina et al. (Eds.): Handbuch Soziologie. Wiesbaden: VS Verlag: 373-390.

Müller, Bernhard; Siedentop, Stefan (Eds.) 2003: Räumliche Konsequenzen des demografischen Wandels. Teil 1. Schrumpfung - Neue Herausforderungen für die Regionalentwicklung in Sachsen, Sachsen-Anhalt und Thüringen. Hannover: ARL.

Müller, Bernhard; Meyer-Künzel, Monika 2007: Soziodemographischer Wandel in Städten und Regionen. Entwicklungsstrategien aus Umweltsicht. Forschungsbericht 205 16 100. Dessau: Umweltbundesamt.

Östlund, Britt 2011: Silver Age Innovators: A New Approach to Old Users. In: Kohlbacher, Florian; Herstatt, Cornelius (Eds.): The Silver Market Phenomenon. Berlin: Springer: 15-26.

Paasi, Ansi 1989: The Media as Creator of Local and Regional Culture. In: The Long-Term Future of Regional Policy - A Nordic View. Report on a Joint NordREFO/OECD Seminar in Reykjavik: 151-165.

Poferl, Angelika 2009: Orientierung am Subjekt? Eine konzeptionelle Reflexion zur Theorie und Methodologie reflexiver Modernisierung. In: Böhle, Fritz; Weihrich, Margit (Eds.): Handeln unter Unsicherheit. Wiesbaden: VS Verlag: 231-264.

Pott, Andreas 2007: Sprachliche Kommunikation durch Raum - das Angebot der Systemtheorie. In: Geographische Zeitschrift 95,1/2: 56-71.

Putzing, Monika 2006: Jugendliche in ländlichen Regionen Ostdeutschlands. Bleiben oder Abwandern? In: Faulde, Joachim; Hoyer, Birgit; Schäfer, Elmar (Eds.): Jugendarbeit in ländlichen Regionen. Entwicklungen, Konzepte und Perspektiven. Weinheim/ München: 73-83.

Rau, Susanne 2013: Räume. Konzepte, Wahrnehmungen, Nutzungen. Frankfurt/New York: Campus. 
Reichertz, Jo 2013: Grundzüge eines kommunikativen Konstruktivismus. In: Keller, Reiner; Knoblauch, Hubert; Reichertz, Jo (Eds.): Kommunikativer Konstruktivismus. Theoretische und empirische Arbeiten zu einem neuen wissenssoziologischen Ansatz. Wiesbaden: Springer VS: 49-68.

Reichertz, Jo o.J.: Konstruktivismus, Kommunikativer [http://kowiki.mykowi.net/index. php/Konstruktivismus,_Kommunikativer, 15.04.2015].

Rosenmayer, Leopold 2010: Die späte Freiheit. Das Alter - ein Stück bewusst gelebten Lebens. Berlin: Severin \& Siedler Verlag.

Stula, Sabrina; Linz, Kathrin 2010: Demographic change in Europe - An Overview. Working Paper No. 4 of the Observatory for Sociopolitical Developments in Europe. Frankfurt a.M.: Institute for Social Work and Social Education (ISS).

Schlottmann, Antje 2005: RaumSprache. Ost-West-Differenzen in der Berichterstattung zur deutschen Einheit. Eine sozialgeographische Theorie. Stuttgart: Franz Steiner Verlag.

Schroer, Markus 2006: Räume, Orte, Grenzen. Auf dem Weg zu einer Soziologie des Raums. Frankfurt a.M.: Suhrkamp.

Schütz, Alfred 1981: Der sinnhafte Aufbau der sozialen Welt. Eine Einleitung in die verstehende Soziologie. Frankfurt a.M.: Suhrkamp.

Srubar, Ilja; Renn, Joachim; Wenzel, Ulrich (Eds.) 2005: Kulturen vergleichen. Sozialund kulturwissenschaftliche Grundlagen und Kontroversen. Wiesbaden: VS Verlag.

Strauss, Anselm L.; Corbin, Juliet 1990: Basics of Qualitative Research. Grounded Theory Procedures and Techniques. Newbury Park: Sage.

Stryjakiewicz, Tadeusz 2013: Residential Change and Demographic Challenge: The Inner City of East Central Europe in the 21st Century. In: Housing Studies 28, 3: 524-526 [doi: 10.1080/02673037.2011.647559].

Tobiassen, Swantje; Husemann, Katharina; Sensevy, Natalie 2012: Mit Kommunikation zivilgesellschaftliches Engagement stärken. Sozialraumanalyse und Befragungsergebnisse der Region um Fahrenwalde. Berlin: Amadeu Antonio Stiftung [http:// www.laendlicher-raum.info/w/files/pdfs/sozialraumanalyse_region-in-aktion.pdf, 06.03.2017].

Weber, Gerlind 2012: Fünf Megatrends prägen Landleben und ländliche Raumbilder. In: Ländlicher Raum 63: 74-78.

Weber, Wolfgang E. J. 2001: Die Bildung von Regionen durch Kommunikation. Aspekte einer neuen historischen Perspektive. In: Hoffmann, Carl A.; Kießling, Rolf (Eds.): Kommunikation und Raum. Konstanz: UVK: 43-67.

Wegner, Martina 2012: Zivilgesellschaftliche Veränderungen. Ideen vom älteren Menschen. In: Beck, Gerald; Kropp, Cordula: Gesellschaft innovativ. Wer sind die Akteure? Wiesbaden: VS Verlag für Sozialwissenschaften: 151-170.

Williams, Penny; Larrison, Jennica; Strokova, Victoria 2012: Social Safety Nets in Europe and Central Asia: Preparing for Crisis, Adapting to Demographic Change, and Promoting. Washington, DC: World Bank.

Witzel, Andreas 1982: Verfahren der qualitativen Sozialforschung. Überblick und Alternativen. Frankfurt/New York: Campus.

Witzel, Andreas 2000: Das problemzentrierte Interview. In: Forum: Qualitative Social Research 1,1: Art 22 [http://www.qualitative-research.net/index.php/fqs/article/ view/1132/2520, 10.05.2015].

Zapf, Wolfgang 1989: Über soziale Innovationen. In: Soziale Welt 40,1/2: 170-183. 


\section{Additional Sources}

citypopulation.de 2014: Cavertitz (Nordsachsen). In: [http://www.citypopulation.de/ php/germany-sachsen_d.php?cityid=14730050, 07.08.2015].

Die Welt, 16.11.2014: Diese Ideen retten unsere Dörfer vor dem Aussterben [http://www. welt.de/wirtschaft/article134390506/Diese-Ideen-retten-unsere-Doerfer-vor-demAussterben.html, 14.06.2015].

Die Welt, 28.11.2011: Wo in Deutschland die Dörfer sterben [http://www.welt.de/ dieweltbewegen/article13739849/Wo-in-Deutschland-die-Doerfer-sterben.html, 14.06.2015].

Eco-world, 09.09.2014: Innovation querfeldein: Klare Sache dank Innovation aus Treptitz [14.06.2015].

Frankfurter Rundschau, 08.04.2015: Die Großstadt boomt, das Land blutet aus [http:// www.fr-online.de/rhein-main/demografischer-wandel-die-grossstadt-boomt--dasland-blutet-aus, 1472796, 30381458.html, 14.06.2015]. http://www.fr.de/rhein-main/ demografischer-wandel-die-grossstadt-boomt-das-land-blutet-aus-a-479872

Freie Presse, 23.11.2014: Ein Dorf baut seine eigene Kläranlage [http://www.freiepresse.de/ NACHRICHTEN/SACHSEN/Ein-Dorf-baut-seine-eigene-Klaeranlage-artikel9044643. php, 14.06.2015].

Lausitzer Rundschau, 08.12.2008: Brandenburgs Randregionen bluten weiter aus [http:// www.Ir-online.de/nachrichten/brandenburg/Brandenburgs-Randregionen-blutenweiter-aus; art25,2302223, 14.06.2015].

Leipziger Volkszeitung, 08.09.2015: Wasser Marsch für neue Anlage in Treptitz [http://www.Ivz.de/Region/Oschatz/Wasser-marsch-fuer-neue-Anlage-in-Treptitz, 14.06.2015].

Leipziger Volkszeitung, 13.11.2014: Dorf Treptitz wird mit HTWK-Umwelt-Konzept als "Ort im Land der Ideen“ ausgezeichnet [http://www.Ivz.de/Leipzig/Bildung/DorfTreptitz-wird-mit-HTWK-Umwelt-Konzept-als-Ort-im-Land-der-Ideen-ausgezeichnet, 14.06.2015].

Statistisches Landesamt des Freistaats Sachsen 2016: 6. Regionalisierte Bevölkerungsvoraus-berechnung für den Freistaat Sachsen 2015-2030. Ausgewählte Ergebnisse für Gemeinde Cavertitz. Dresden [https://www.statistik.sachsen.de/ download/080 RegBev Prognose-PDF/PROG_Cavertitz_14730050.pdf, 15.01.2017].

Statistisches Landesamt des Freistaats Sachsen 2016: Landkreisinformation. Landkreis Nordsachsen. Dresden [https://www.statistik.sachsen.de/download/010_GB-Bev/LK_ Nordsachsen.pdf, 15.01.2017].

Süddeutsche Zeitung, 04.10.2012: Leere Landschaften [http://www.sueddeutsche.de/ leben/bevoelkerungsentwicklung-wie-der-demografische-wandel-deutschland-veraendert-1.1486334-2, 14.06.2015].

Torgauer Zeitung, 02.05.2014: Spät ja, aber noch nicht zu spät [http://www. torgauerzeitung.com/Default.aspx?t= NewsDetailModus \%2875412\%29, 14.06.2015].

VÖG Treptitz e.V., 2014. In: http://treptitz.de/land-der-ideen/, 16.07.2015.

Prof. Dr. Gabriela B. Christmann ( $₫)$. Leibniz Institute for Research on Society and Space. Leibniz, Germany. E-mail: Gabriela.Christmann@leibniz-irs.de

URL: https://leibniz-irs.de/en/people-careers/staff/person/gabriela-christmann-0903/ 


\section{Comparative Population Studies}

wWW.comparativepopulationstudies.de

ISSN: 1869-8980 (Print) - 1869-8999 (Internet)

\section{Published by}

Prof. Dr. Norbert F. Schneider

Federal Institute for Population Research D-65180 Wiesbaden / Germany

\section{(cc) BY-SA}

2017

\section{Managing Editor}

Frank Swiaczny

\section{Assistant Managing Editor}

Katrin Schiefer

\section{Copy Editor}

(Selected Articles in German)

Dr. Evelyn Grünheid

\section{Layout}

Beatriz Feiler-Fuchs

E-mail: cpos@bib.bund.de

\section{Scientific Advisory Board}

Paul Gans (Mannheim)

Karsten Hank (Cologne)

Johannes Huinink (Bremen)

Michaela Kreyenfeld (Rostock)

Marc Luy (Vienna)

Notburga Ott (Bochum)

Peter Preisendörfer (Mainz)

Nikola Sander (Groningen)

Zsolt Spéder (Budapest)

\section{Board of Reviewers}

Martin Abraham (Erlangen)

Laura Bernardi (Lausanne)

Hansjörg Bucher (Bonn)

Claudia Diehl (Konstanz)

Andreas Diekmann (Zurich)

Gabriele Doblhammer-Reiter (Rostock)

Jürgen Dorbritz (Wiesbaden)

Anette Eva Fasang (Berlin)

E.-Jürgen Flöthmann (Bielefeld)

Alexia Fürnkranz-Prskawetz (Vienna)

Beat Fux (Salzburg)

Joshua Goldstein (Berkeley)

Sonja Haug (Regensburg)

Hill Kulu (Liverpool)

Aart C. Liefbroer (The Hague)

Kurt Lüscher (Konstanz)

Emma Lundholm (Umeå)

Nadja Milewski (Rostock)

Dimiter Philipov (Vienna)

Roland Rau (Rostock)

Tomáš Sobotka (Vienna)

Jeroen Spijker (Barcelona)

Olivier Thévenon (Paris)

Helga de Valk (Brussels)

Heike Trappe (Rostock)

Michael Wagner (Cologne) 